\title{
ETOS KERJA PEREMPUAN DI SEKTOR PERIKANAN PADA KAWASAN MASTERPLAN PERCEPATAN DAN PERLUASAN PEMBANGUNAN EKONOMI INDONESIA (MP3EI) DAN STRATEGI PEMBERDAYAAN DAN PENGEMBANGAN EKONOMI (Studi Kasus Perempuan Pembudidaya Rumput Laut di Nusa Penida, Bali) Ethos Work of Women in Fishery Sector in The Regional Masterplan
for Acceleration and Expansion of Economic Development and Their
Strategies For Economics Empowerment and Development
(Case Study on Women Cultivator of the Seaweed in Nusa Penida, Bali)
}

\author{
"Nurlaili dan Fatriyandi Nur Priyatna \\ Balai Besar Penelitian Sosial Ekonomi Kelautan dan Perikanan \\ Gedung Balitbang KP I Lt. 4 \\ Jalan Pasir Putih Nomor 1 Ancol Timur, Jakarta Utara \\ Telp: (021) 64711583 Fax: 64700924 \\ "email: lelykesa_antrop@yahoo.com \\ Diterima 4 April 2014 - Disetujui 6 Juni 2014
}

\begin{abstract}
ABSTRAK
Tulisan ini bertujuan untuk menggambarkan etos kerja perempuan pembudidaya rumput laut di Nusa Penida dan dikaitkan dengan strategi pemberdayaan dan pengembangan ekonomi dalam konsep Masterplan Percepatan dan Perluasan Pembangunan Ekonomi Indonesia (MP3EI). Penelitian dilakukan pada tahun 2013 dengan fokus pada kawasan minapolitan Nusa Penida di 3 (tiga) gugusan pulau: Nusa Besar atau Nusa Penida, Nusa Lembongan, dan Nusa Ceningan. Metode penelitian menggunakan pendekatan kualitatif. Teknik pengumpulan data wawancara mendalam (depth interview) dan pengamatan (observasi). Analisis data menggunakan deskriptif eksplanatoris dimana data-data yang dikumpulkan digambarkan secara rinci kemudian digunakan untuk menjelaskan strategi pemberdayaan dan pengembangan ekonomi yang ada. Hasil penelitian menunjukkan bahwa perempuan pembudidaya rumput laut di Nusa Penida memiliki etos kerja yang tinggi, rajin, memiliki kesungguhan serta kemauan bekerja keras membantu suami dalam mencari nafkah. Pandangan perempuan pembudidaya rumput laut di Nusa Penida tentang pekerjaan yaitu bahwa tidak ada pekerjaan yang berat, sudah ada pembagian kerja dan saling membantu antara laki-laki dengan perempuan sesuai dengan keyakinan yang mereka anut. Strategi pemberdayaan dan pengembangan perempuan pembudidaya rumput laut dalam mendukung percepatan dan perluasan pembangunan ekonomi yaitu dengan membuat kebijakan yang memihak melalui pengakuan peran dan partisipasi mereka serta melakukan pendampingan dan pelatihan-pelatihan yang sesuai dengan kebutuhan mereka.
\end{abstract}

Kata Kunci: etos kerja, strategi pemberdayaan, pengembangan ekonomi, MP3EI

\begin{abstract}
This paper aims to describe the work ethos female seaweed farmers in Nusa Penida and strategies associated with empowerment and economic development in the concept MP3El. The study was conducted in 2013 with a focus on Nusa Penida Minapolitan in three (3) group of islands: Nusa Large or Nusa Penida, Nusa Lembongan and Nusa Ceningan. Research method used was a qualitative approach with in-depth interview data collection techniques and observation. Analysis of the data used descriptive explanatory by which data collected were described in detail and then were used to explain the strategy of empowerment and economic development there. Results showed that women seaweed farmers in Nusa Penida has a high work ethos, diligent, a seriousness and willingness to work hard to help her husband in making a living. View of female seaweed farmers in Nusa Penida on the job is that there is no heavy work, the existing division of labor and mutual help between men and women in accordance with the faith that they profess. Women's empowerment and development strategy seaweed farmers in supporting the acceleration and expansion of economic development is to create policies that favor through recognition of their role and participation as well as mentoring and training appropriate to their needs.
\end{abstract}

Keywords: work ethic, empowerment strategies, economic development, MP3EI 


\section{PENDAHULUAN}

Berbagai artikel mengenai perempuan sudah banyak dapat kita temui Peran perempuan dari berbagai aspek, baik di lingkup rumah tangga maupun publik baik dari kacamata kesetaraan maupun ketidaksetaraan gender. Tulisan mengenai perempuan Bali, sudah banyak digambarkan mengenai bagaimana peranannya di berbagai aspek kehidupan. Sebuah tulisan Luh Ayu Tirtayani menggambarkan tentang pemaknaan peran wanita Bali di Desa Adat Kuta yang menggambarkan tidak hanya di lingkup rumah tangga namun juga publik. Berbagai tulisan tentang peran perempuan tidak hanya pada sektor pertanian dan pariwisata, namun juga pada sektor perikanan. Tulisan Witomo \& Hikmah (2012) menggambarkan peran perempuan pembudidaya rumput laut di Desa Batu Nunggul, Nusa Penida. Tulisan ini menggambarkan peran perempuan dalam lingkup rumah tangga dan publik dilihat dari etos kerja yang merupakan bagian dari kebudayaan masyarakat Bali dikaitkan dengan strategi pemberdayaan dan pengembangan ekonomi yang harus dilakukan dalam rangka mempercepat pertumbuhan pembangunan sektor kelautan dan perikanan, khususnya di koridor Bali-Nusa Tenggara.

Konsep MP3El merupakan sebuah pola induk perencanaan pemerintah Indonesia untuk mempercepat realisasi perluasan pembangunan ekonomi dan pemerataan kemakmuran sehingga dapat dinikmati secara merata di masyarakat. Percepatan dan perluasan pembangunan ekonomi tersebut didukung berdasarkan potensi demografi dan kekayaan sumber daya alam, dan keuntungan geografis masing-masing daerah. Konsep ini lahir pada tahun 2011 dengan melibatkan berbagai lembaga yang ada di Indonesia. Kementerian Kelautan dan Perikanan merupakan salah satu lembaga yang turut serta berada di dalam pokja (kelompok kerja) MP3EI dengan mengembangkan konsep industrialisasi dalam sektor kelautan dan perikanan.

Delapan faktor dalam mendukung industrialisasi dalam sektor kelautan dan perikanan yaitu 1) terjaminnya ketersediaan sumber daya ikan secara berkesinambungan, 2) sarana dan prasarana infrastruktur yang memadai, 3) pengembangan ragam inovasi dan penerapan teknologi secara masif, 4) komoditas kelautan dan perikanan yang bernilai tambah tinggi, 5) SDM yang handal dan kompeten, 6) pasar potensial yang dikelola baik,
7) dukungan investasi dari para pelaku usaha, 8) regulasi pemerintah yang kondusif. Industrialisasi ini pada dasarnya ditujukan dalam rangka mendukung terlaksananya empat pilar pembangunan nasional yakni pro-growth, pro-job, pro-poor, dan pro-environment (Antara, 2013)

Salah satu faktor penting dalam industrialisasi adalah sumberdaya manusia yang handal dan kompeten. Tanpa sumberdaya manusia yang handal dan kompeten ketujuh faktor lainnya tidak akan berarti apapun dalam mencapai tujuan pembangunan. Salah satu faktor yang mempengaruhi kualitas sumberdaya manusia adalah etos kerja karena etos menentukan penilaian manusia atas suatu pekerjaan sehingga etos kerja akan menentukan pula hasil-hasilnya. Semakin progresif etos kerja suatu masyarakat, semakin baik hasil-hasil yang akan dicapai baik secara kuantitatif maupun kualitatif (Siswanto, 2011).

Tujuan tulisan ini adalah menggambarkan etos kerja pembudidaya rumput laut perempuan di Nusa Penida. Diharapkan dengan adanya tulisan ini maka kebijakan pembangunan dengan strategi pemberdayaan dan pengembangannya tidak lagi mengabaikan peran perempuan pembudidaya rumput laut khususnya di Nusa Penida.

\section{METODOLOGI}

\section{Konsep Etos Kerja}

Berbicara mengenai industrialisasi dan pembangunan ekonomi tidak akan pernah dapat kita lepaskan dengan faktor-faktor non ekonomi, dan kebudayaan. Faktor budaya sangat mempengaruhi perilaku ekonomi sebuah masyarakat. Salah satu faktor yang sangat penting dalam perilaku ekonomi masyarakat adalah etos kerja. Etos kerja dapat dipandang dari dua perspektif, pertama menggambarkan sikap mental yang ada dan kedua sebagai sikap kehendak yang dituntut agar dikembangkan. Etos kerja merupakan nilai diri seseorang sebagai paduan dari kognisi (cognition), afeksi (affection), dan konasi (conation). Kognisi adalah proses memahami (process of knowing) yang bersangkutan dengan pikiran; afeksi adalah perasaan yang ditimbulkan oleh perangsang dari luar; dan konasi adalah aspek psikologis yang berkaitan dengan upaya atau perjuangan. Etos kerja dapat dilihat sebagai sikap dasar seseorang atau sekelompok orang dalam melakukan pekerjaan (Siswanto, 2011). 
Etos merupakan sumber motivasi seseorang dalam berbuat, misalnya apakah pekerjaan dianggap sebagai keharusan demi hidup, apakah pekerjaan terikat pada identitas diri dan sosial, atau lebih lanjut dapat ditanyakan apakah yang menjadi sumber pendorong partisipasi seseorang dalam berbagai hal. Etos juga merupakan landasan ide, cita, atau pikiran yang akan menentukan sistem tindakan (system of action). Sumber pendorong etos kerja adalah kebudayaan masyarakat yang bersangkutan. Kebudayaan merupakan sistem pengetahuan yang dijadikan pedoman dalam berperilaku.

\section{Lokasi dan Pendekatan Penelitian}

Penelitian dilakukan di Kecamatan Nusa Penida, Kabupaten Klungkung, Propinsi Bali. Lokasi penelitian terdiri dari tiga gugus pulau yaitu Nusa Besar atau Nusa Penida, Nusa Lembongan dan Nusa Ceningan. Lokasi penelitian merupakan sentra usaha budidaya rumput laut. Waktu Penelitian dilakukan pada tahun 2013. Data dan informasi diporoleh dari studi literatur terkait dengan hasilhasil penelitian yang telah dilakukan di lokasi yang sama.

Penelitian menggunakan pendekatan kualitatif dengan teknik pengumpulan data wawancara mendalam (depth interview) dan pengamatan (observasi). Analisis data menggunakan analisis deskriptif kualitatif eksplanatoris dimana data-data yang dikumpulkan digambarkan secara rinci kemudian digunakan untuk menjelaskan strategi pemberdayaan dan pengembangan ekonomi masyarakat. Karakteristik informan yang dipilih adalah perempuan pembudidaya rumput laut. Data sekunder dikumpulkan untuk mendukung data-data primer yang ada. Data sekunder diperoleh melalui studi literatur terkait dengan hasil-hasil penelitian yang telah dilakukan di lokasi yang sama.

\section{HASIL DAN PEMBAHASAN}

\section{Potensi Usaha Budidaya Rumput Laut Nusa Penida}

Nusa Penida terletak di Kabupaten Klungkung, salah satu kabupaten di Propinsi Bali. Secara fisik, dua pertiganya merupakan kepulauan dengan luas wilayah $20.284 \mathrm{Ha}$, sedangkan sepertiga wilayahnya merupakan daratan yang menyatu dengan pulau Bali. Kecamatan Nusa Penida merupakan kecamatan kepulauan dengan 3 gugusan pulau yaitu pulau Nusa Penida atau Nusa besar, Nusa Lembongan, dan Nusa Ceningan, dengan 16 desa administratif. Pulau Nusa Penida mempunyai luas wilayah $192,72 \mathrm{~km}^{2}$ dan secara administratif terbagi dalam 14 desa, Pulau Nusa Lembongan memiliki luas $8,89 \mathrm{~km}^{2}$ yang terbagi atas 2 desa, serta Pulau Nusa Ceningan dengan luas $3,16 \mathrm{~km}^{2}$. Batas utara dan barat Nusa Penida adalah Selat Badung, sebelah timur berbatasan dengan Selat Lombok dan sebelah selatan dengan Samudra Indonesia.

Mata pencaharian masyarakat di Nusa Penida umumnya di sektor perikanan, pertanian, peternakan, perdagangan dan sektor jasa. Selain di perikanan, pemanfaatan lahan di masyarakat

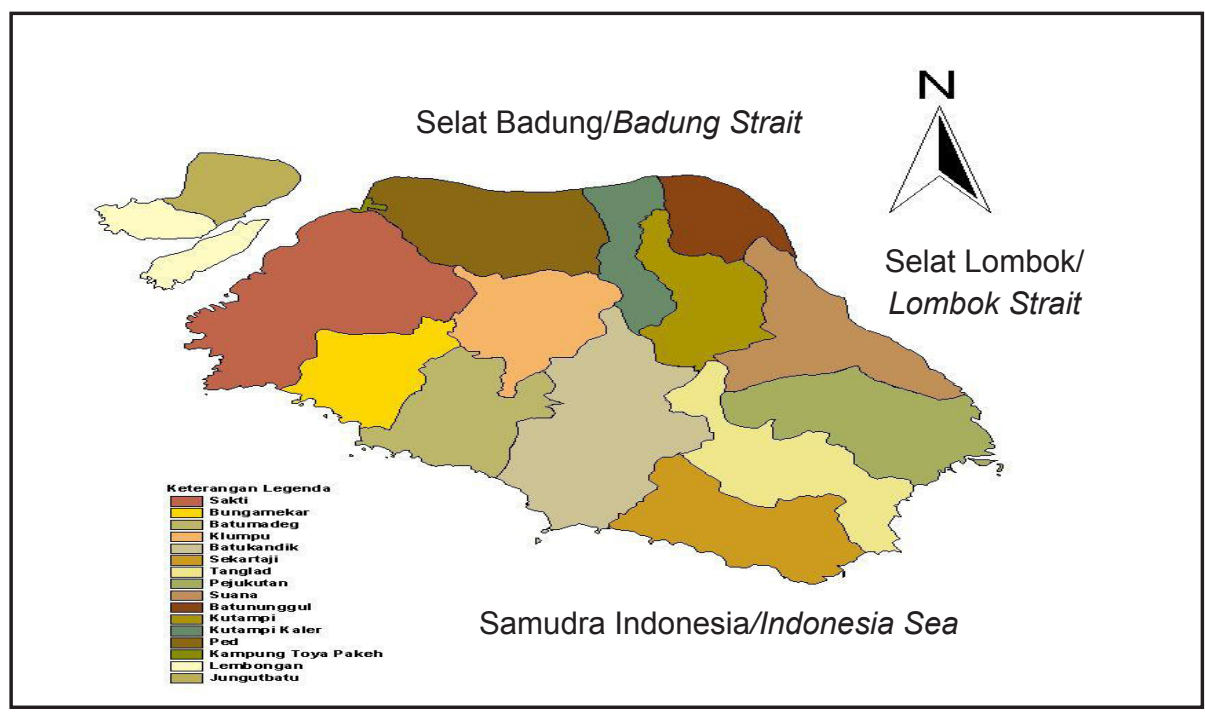

Gambar 1.Peta Kecamatan Nusa Penida

Figure 1. Map of Nusa Penida Sub-district

Sumber/Source : Nasution et al. (2013) 
umumnya digunakan untuk tegalan, perkebunan, dan pekarangan. Khusus di Nusa Lembongan, pemanfaatan tanah termasuk juga untuk hutan lindung (mangrove). Peternakan sapi dan babi juga cukup intensif di Nusa Penida. Kondisi geografis kepulauan di Nusa Penida memberikan kekayaan potensi sumberdaya yang dapat dimanfaatkan untuk kesejahteraan masyarakatnya. Sumberdaya kelautan dan perikanan merupakan sumberdaya yang sangat potensial untuk dikembangkan sebagai mata pencaharian di Nusa Penida. Panjang pantai kepulauan Nusa Penida yang mencapai 83,50 km dapat dimanfaatkan untuk sumber perekonomian baik perikanan tangkap, budidaya, maupun wisata bahari. Namun, potensi yang besar tersebut masih belum dimanfaatkan secara maksimal. Secara keseluruhan, peningkatan produktivitas usaha perikanan dan volume perdagangan hasil perikanan di Pangkalan Pendaratan Ikan (PPI) dinilai belum mencapai hasil yang maksimal.

Selain perikanan tangkap, di Nusa Penida berkembang usaha budidaya rumput laut. Hampir 90\% nelayan Nusa Penida juga memiliki areal budidaya rumput laut. Di Desa Suana $100 \%$ nelayan memiliki areal rumput laut. Di Batununggul 90\% nelayan memiliki areal rumput laut. Hal ini menjadi salah satu dasar penetapan Nusa Penida sebagai salah satu lokasi kawasan minapolitan budidaya rumput laut. Komoditas rumput laut merupakan produk unggulan di sektor perikanan, bahkan budidaya rumput laut menjadi salah satu mata pencaharian utama di kepulauan Nusa Penida.

Pada tahun 2008, melalui Peraturan Bupati Klungkung Nomor 27 Tahun 2008 Kecamatan Nusa Penida ditetapkan sebagai kawasan minapolitan khususnya untuk komoditas rumput laut. Metode budidaya rumput laut yang digunakan oleh masyarakat adalah sistem lepas dasar dengan jenis yang dibudidayakan E. spinosum dan E. cottonii. Luas lahan yang telah dimanfaatkan masyarakat untuk budidaya rumput laut di Nusa Penida dari hasil survey The Nature Conservancy (TNC) pada tahun 2009 adalah 308 Ha (Welly et al., 2012) . Hingga saat ini pengembangan budidaya rumput laut telah mencapai $45 \%$ dari luas areal pantai di Nusa Penida. Jenis rumput laut cottonii tumbuh subur di Nusa Lembongan tepatnya di selat antara Lembongan dan Ceningan. Total hasil panen rumput laut setiap rumah tangga rata-rata mencapai 40 50 ton per panen (35 hari). Namun hingga saat ini harga rumput laut masih sangat berfluktuasi, pada bulan September 2013, harga rumput laut jenis spinosum sp dengan kadar air 30\% antara
Rp 2.000 - 3.900 per kg, untuk jenis Cottonii Rp 10.000 per kg. Kisaran pendapatan bersih rata-rata Rp. 300.000 / petak (10x10 m²).

Penjemuran menggunakan meja jemur dan para-para masih belum banyak dilakukan, hanya beberapa pembudidaya. Alasannya selain keterbatasan lahan/tanah untuk bangunan dan harga rumput laut tidak didasarkan kualitasnya.

Pengecekan kualitas kebersihan rumput laut biasanya dilakukan oleh pedagang pengumpul di lokasi pembudidaya. Hal ini dilakukan karena tingginya tingkatpersaingan diantara para pedagang, sehingga mereka mau menerima rumput laut dalam kondisi kurang bersih. Pedagang pengumpul melakukan pekerjaan untuk memisahkan rumput laut dengan pasir ketika akan dijual kepada pedagang di luar kota. Hal ini dilakukan karena perbedaan harga terhadap kualitas rumput laut.

Hasil budidaya rumput laut umumnya dijual kepada pedagang pengumpul yang ada di masingmasing lokasi pembudidaya rumput laut. Penjualan rumput lautnya kepada pedagang pengumpul mana saja. Pada umumnya mereka sangat tergantung pada pengumpul untuk menjual hasil panen. Pembudidaya rumput laut yang sudah bergabung dalam kelompok menjual hasil panennya kepada koperasi kelompok yang sudah terbentuk. Selain kepada pengumpul lokal, pembudidaya rumput laut juga menjual kepada pedagang antar pulau. Pedagang pengumpul dan koperasi tingkat desa, rumput laut dijual ke pedagang pengumpul yang ada di Kota Nusa Penida. Saluran pemasaran rumput laut berikutnya adalah pedagang besar di Kota Denpasar dan dijual kepada eksportir, di Surabaya atau Makassar. Ekspor rumput laut ke China, Taiwan, Korea dan Jepang. Gambar rantai pemasaran rumput laut di Nusa Penida dapat dilihat pada Gambar 2.

Satu tradisi unik yang ditemui masyarakat di Nusa Penida adalah tradisi munuh. Tradisi munuh adalah tradisi mengambil sisa panen rumput laut yang dilakukan bukan oleh pemilik areal rumput laut atau boleh siapa saja. Tiap desa memiliki aturan munuh yang berbeda. Di Desa Semaya, tradisi munuh tidak boleh dilakukan oleh orang lain, sisa hasil panen hanya boleh diambil oleh pemilik areal rumput laut. Namun, jika sisa panen rumput laut masuk ke tambak milik orang lain maka pemilik tambak tersebut berhak mengambil munuhnya. Perbedaan aturan munuh ini disebabkan karena tiap lokasi memiliki jenis rumput laut yang berbeda. 


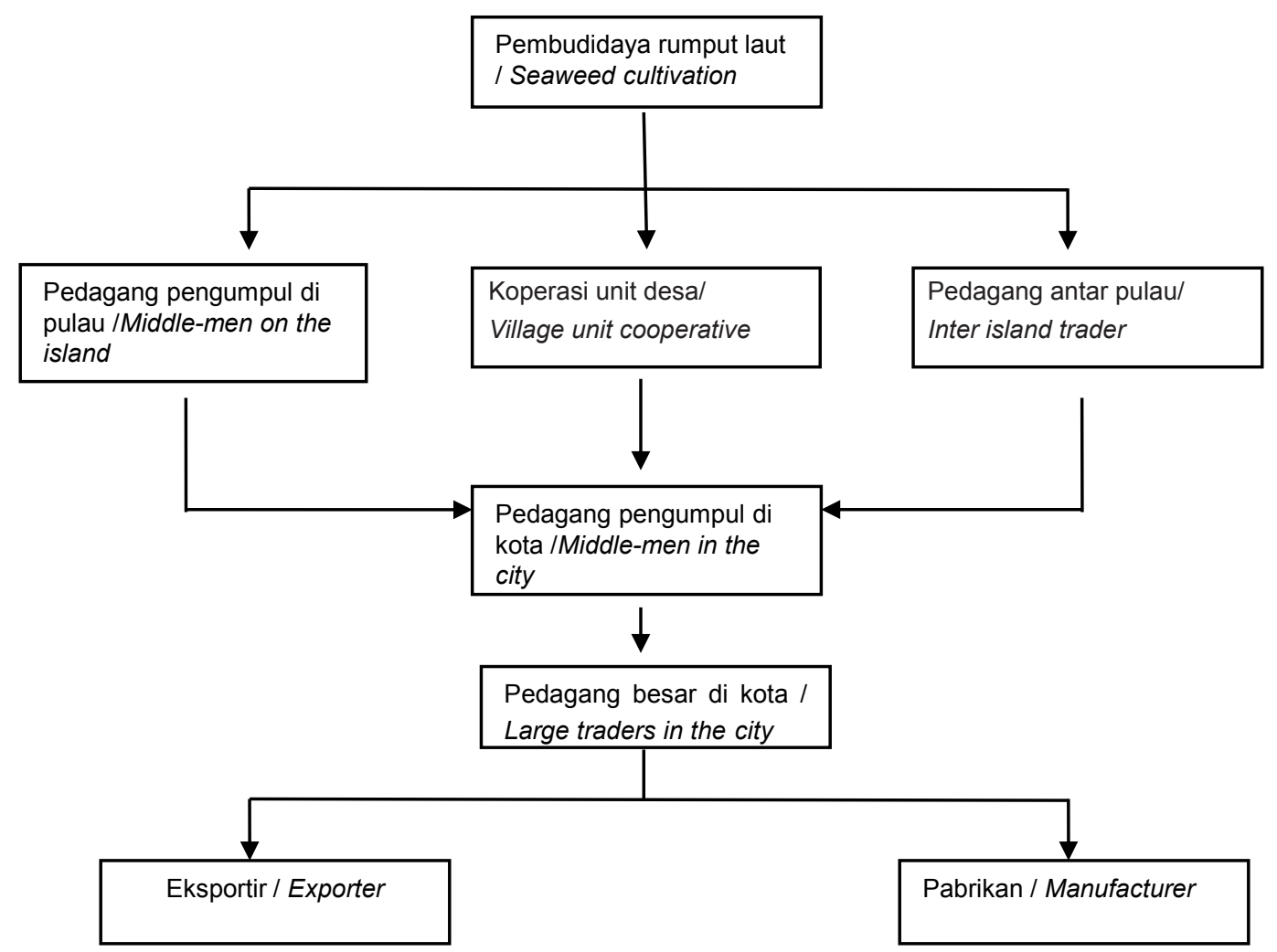

\section{Gambar 2. Saluran Pemasaran Rumput Laut di Nusa Penida, Kabupaten Klungkung Figure 2. Marketing Channel Seaweed in Nusa Penida, Klungkung District}

(Diadopsikan/Adoption: Nasution et al. (2013)

Lokasi yang dominan ditanami jenis rumput laut cottonii maka tradisi munuh dilarang. Hal ini disebabkan karena jenis rumput laut cottonii memiliki harga jual yang tinggi. Di lokasi lain yang didominasi oleh jenis rumput laut spinosum maka tradisi munuh diperbolehkan, siapa saja berhak mengambilnya.

Selain perikanan tangkap dan budidaya rumput laut, pengolahan hasil perikanan di Nusa Penida juga memiliki potensi yang cukup besar. Perkembangan sektor pariwisata membuka peluang lebih luas. Hingga saat ini pengolahan hasil perikanan di Nusa Penida masih belum berkembang. Pemasaran produk olahan hasil perikanan masih sebatas dijual ke pasar atau warung-warung lesehan. Untuk rumput laut, jenis olahan yang sudah diproduksi adalah dodol, manisan, kerupuk, pepes, selai dan jus rumput laut dengan jumlah produksi yang masih sedikit dan masih sebatas pesanan. Pola pemasaran hasil pengolahan produk ini masih sangat sederhana dan membutuhkan perluasan akses pasar. Hal ini menyebabkan pola produksinya masih sangat bergantung pada pemasar.
Sudah ada pelaku usaha pengolahan yang memproduksi olahan yang dipasarkan di satu tempat objek wisata. Hal ini disebabkan karena tempat wisata tersebut merupakan milik pribadi keluarganya sehingga lebih mudah untuk memantau penjualan. Umumnya jumlah produksi rata-rata 10 $\mathrm{kg} /$ panen siklus produksi dua kali dalam seminggu. Kegiatan pengolahan hasil perikanan hanya dilakukan di lokasi Nusa Lembongan. Pengolahan hasil perikanan di Nusa Penida baru pada tahapan inisiasi pembentukan Kelompok Usaha Bersama (KUB) introduksi teknologi, dan pengetahuan beberapa jenis pengolahan.

Prospek pemasaran pengolahan hasil perikanan di Nusa Penida cukup besar mengingat sektor wisata cukup berkembang di wilayah tersebut. Namun, hingga saat ini usaha pengolahan hasil perikanan masih termasuk dalam kategori sederhana baik dari jenis olahan maupun teknologi pembuatan dan pengemasannya. Bantuan teknologi pengolahan dari pemerintah maupun pihak lain belum dimanfaatkan secara optimal. Salah satu faktor yang menyebabkan belum berkembangnya jenis usaha pengolahan hasil perikanan adalah 
karena alokasi waktu perempuan yang lebih banyak bekerja di usaha budidaya rumput laut.

\section{Peran Perempuan dalam Rumah Tangga dan Usaha Budidaya Rumput Laut}

Berdasarkan data statistik di bawah ini, jumlah perempuan di Nusa Penida lebih banyak dibandingkan dengan laki-laki. Perempuan di Nusa Penida seperti pada umumnya di Bali bahwa perannya mereka tidak hanya sebagai istri/ibu rumah tangga juga dalam berbagai aspek kehidupan termasuk menyumbang pendapatan rumah tangga.

Peran perempuan dalam berbagai bidang kehidupan sudah banyak dilihat baik di ruang privat maupun ruang publik. Perempuan tidak hanya mengerjakan tugasnya sebagai istri dan ibu rumah tangga, mereka juga membantu suami dalam mencari nafkah. Bahkan terkadang peran perempuan dalam aktivitas ekonomi menunjukkan dominasinya. Hal ini sudah ditunjukkan dari berbagai hasil penelitian (Chrysantini (2010); Nurlaili \& Koeshendrajana (2010); Witomo \& Hikmah (2012):
Nasution et al. (2013)) serta masih banyak lagi penelitian lainnya yang menunjukkan bahwa kaum perempuan memberikan alokasi waktu yang besar bahkan melebihi porsi waktu yang diberikan oleh kaum laki-laki.

Budidaya rumput laut telah berkembang di Nusa Penida sejak tahun 1980-an dan sudah merupakan matapencaharian utama sebagian besar masyarakat di samping nelayan dan pertanian. Usaha rumput laut ini dilakukan mayoritas oleh kaum perempuan, mulai dari tahap persiapan, produksi, dan pasca produksi. Hasil penelitian Witomo \& Hikmah (2012) menunjukkan bahwa sebanyak 76,8 $\%$ perempuan di Desa Batununggul di Nusa Penida terlibat dalam pekerjaan pembudidaya rumput laut. Besarnya peran perempuan dalam usaha budidaya rumput laut berpengaruh pada besarnya kontribusi perempuan dalam pendapatan ekonomi rumah tangga di Nusa Penida.

Alokasi waktu yang diberikan kaum perempuan pada usaha budidaya rumput laut lebih besar dibandingkan laki-laki, mulai dari persiapan, penanaman, pemeliharaan, panen dan

Tabel 1. Komposisi Jumlah Laki-laki dan Perempuan Menurut Data di Kecamatan Nusa Penida Tahun 2011

Table 1. Composition Number of Men and Women Based on Data on Nusa Penida Districk in 2011.

\begin{tabular}{lrrr}
\hline Desa/Village & Laki-laki/Men & Perempuan/Women & Total/Total \\
\hline Sakti & 1,770 & 1,791 & 3,561 \\
Bunga Mekar & 1,176 & 1,297 & 2,473 \\
Batumadeg & 1,206 & 1,175 & 2,381 \\
Klumpu & 1,658 & 1,663 & 3,321 \\
Batukandik & 1,886 & 2,354 & 4,240 \\
Sekartaji & 770 & 843 & 1,613 \\
Tanglad & 1,013 & 1,167 & 2,180 \\
Pejukutan & 1,660 & 1,7801 & 3,440 \\
Suana & 1,645 & 1,684 & 3,329 \\
Batununggul & 2,048 & 2,260 & 4,308 \\
Kutampi & 1,507 & 1,561 & 3,068 \\
Kutampi Kaler & 1,393 & 1,286 & 2,679 \\
P e d & 1,927 & 1,897 & 3,824 \\
Toyepakeh & 279 & 318 & 597 \\
Lembongan & 2,203 & 2,088 & 4,291 \\
Jungutbatu & 1,566 & 1,689 & 3,255 \\
Jumlah/amount & 23,707 & 24,853 & 48,560 \\
\hline
\end{tabular}

Sumber: BPS (Registrasi Penduduk) / Source:BPS (Civil Registration), 2012 
pasca panen. Laki-laki umumnya hanya terlibat pada kegiatan penanaman dan panen rumput laut. Pada tahap persiapan kaum perempuan memiliki peran mempersiapkan tali yang akan digunakan untuk mengikat rumput laut, mengikatkan bibit rumput laut ke tali-tali yang sudah dipersiapkan dan mempersiapkan yang akan diikat. Biasanya waktu yang dibutuhkan pada tahap persiapan ini tidak terbatas, dilakukan sejak selesai mengerjakan pekerjaan rumah tangga sampai menjelang tidur malam. Umumnya kaum perempuan memanfaatkan waktu luangnya dengan mengikat tali temali, bahkan sambil bersenda gurau mereka juga melakukan pekerjaan tersebut.

Hal lainnya yang dilakukan oleh kaum perempuan pada tahap persiapan adalah memilah bibit dari hasil panen. Tahapan persiapan yang dilakukan oleh perempuan meliputi mempersiapkan tali pengikat rumput laut, mempersiapkan bibit yang akan diikat, mengikatkan bibit rumput laut ke tali-tali / mengikat bibit dari hasil penelitian rumput laut yang dipanen dipilah dan dipisahkan antara yang akan dijual atau dijadikan bibit. Setelah mendapatkan bibit rumput laut, maka tugas selanjutnya adalah mengikatkan bibit ke tali temali yang sudah disiapkan. Kaum perempuan sangat mahir melakukannya. Pekerjaan ini dilakukan bersama-sama dengan beberapa anggota kerabat (Tabel 2).

Setelah ikatan-ikatan rumput laut sudah selesai maka tahap berikutnya adalah membawanya ke pantai untuk ditanam. Umumnya pekerjaan ini dilakukan bersama-sama dengan suami. Waktu penanaman rumput laut adalah pada saat air laut surut, biasanya pada pagi hari. Pasang surut air laut memang sangat berpengaruh pada usaha budidaya rumput laut. Jika pukul 02.00 WITA dini hari air sudah surut maka mereka harus segera bangun dan memulai pekerjaan mereka seperti memanen atau memasang rumput laut. Pada tahap penanaman biasanya kaum perempuan membantu memegangkan tali bersama dengan laki-laki. Perempuan juga terlibat dalam pemeliharaan. Umumnya mereka menggunakan perahu kecil dan mendayung ke lokasi lahan budidaya rumput laut. Sambil menunggu panen, para perempuan tidak serta merta menganggur, mereka umumnya tiap hari membantu kerabat yang membutuhkan tenaga pada tahap persiapan atau pasca panen. Mereka yang bukan pemilik rumput laut biasanya terlibat dalam proses pasca panen dan persiapan. Bantuan ini mereka berikan secara ikhlas tanpa

Tabel 2. Keterlibatan Peran Perempuan pada Tahap Persiapan.

Table 2. The Involvement of Women Role on Preparation Stage.

\begin{tabular}{|c|c|}
\hline Waktu/Time & Aktivitas/Activity \\
\hline $\begin{array}{l}\text { Tidak terbatas, sejak selesai mengerjakan pekerjaan } \\
\text { rumah tangga sampai menjelang tidur malam (05.00- } \\
22.00 \text { WITA) / An limited, since finished do housework until } \\
\text { at bedtime night (05.00-22.00 WITA) }\end{array}$ & $\begin{array}{l}\text { - Mempersiapkan tali yang akan digunakan } \\
\text { untuk mengikat rumput laut / Prepare a rope } \\
\text { used to fasten seaweed. } \\
\text { - Mempersiapkan bibit rumput lau/ Prepare } \\
\text { seaweed seed } \\
\text { - Mengikatkan bibit rumput laut ke tali-tali yang } \\
\text { sudah dipersiapkan / Fastens seaweed seed } \\
\text { to ropes that already prepared }\end{array}$ \\
\hline
\end{tabular}

Sumber: Data primer diolah (2013) / Source primary data processed (2013)

Tabel 3. Keterlibatan Peran Perempuan pada Tahap Penanaman.

Table 3. The Involvement of Women Role on Cultivation Stage.

\begin{tabular}{ll}
\multicolumn{1}{c}{ Waktu/Time } & \multicolumn{1}{c}{ Aktivitas/Activity } \\
\hline Pada saat air laut surut, biasanya pada pagi hari/Jika & Bersama-sama dengan suami membawa \\
pukul 02.00 WITA air sudah surut maka mereka harus & rumput laut ke pantai untuk ditanam perempuan \\
segera bangun dan memulai pekerjaan / When sea & membantu memegangkan tali bersama dengan \\
water recede usually in the morning lif 2 am wita water & laki-laki/ Together with the husband bring \\
ran off and they should get up and began the work & $\begin{array}{l}\text { seaweed to beach for planted women help held } \\
\text { ropes together with men }\end{array}$
\end{tabular}

Sumber: Data primer diolah (2013) / Source primary data processed (2013) 
diminta dan diberi bayaran (Tabel 3).

Keterlibatan perempuan pada usaha budidaya rumput laut tidak hanya pada tahap persiapan, penanaman dan pemeliharaan. Pada tahap panen, kaum perempuan terlibat dalam mengambil rumput laut di tambak. Pekerjaan ini biasanya dilakukan bersama-sama dengan laki-laki, namun juga dapat dilakukan sendiri. Mereka dapat menggunakan perahu kecil atau yang disebut dengan kole untuk menjangkau tambak yang jaraknya tidak jauh dari pantai. Setelah panen, rumput laut dibawa ke pantai untuk kemudian dicuci dan dibawa ke daratan. Pada tahap pasca panen, kaum perempuan terlibat dalam pekerjaan memilah rumput laut yang bisa dijual dengan rumput laut yang akan dijadikan bibit. Setelah memilah, rumput laut yang siap untuk dijual dibawa ke penjemuran. Bibit rumput laut kemudian diikat kembali dengan tali yang sudah disiapkan (Tabel 4).

Perempuan menjadi tulang punggung usaha budidaya rumput laut di Nusa Penida. Tidak ada pemisahan antara pekerjaan laki-laki dan perempuan, umumnya dapat dilakukan secara bersama-sama. Kaum perempuan melakukan pekerjaan seperti mengangkat rumput laut dari pantai ke daratan dan juga rumput laut yang akan dijemur. Besarnya alokasi waktu yang diberikan oleh kaum perempuan dibandingkan laki-laki dalam setiap siklus usaha budidaya rumput laut menunjukkan betapa besarnya peran mereka dalam usaha rumput laut. Menurut mereka hal ini juga merupakan salah satu cara untuk mengisi waktu santai mereka. Jika tidak ada pekerjaan rumput laut, maka waktu santai mereka hanya diisi dengan kegiatan mencari kutu atau bergosip saja (Tabel 5).

\section{Etos Kerja Perempuan Pembudidaya Rumput Laut}

Berbicara mengenai Bali tidak hanya berbicara mengenai potensi alam dan seninya yang indah yang dapat dijadikan obyek wisata. Bali juga memiliki kebudayaan yang merupakan hasil interaksi antara alam dengan sistem keyakinan Hindu yang mendominasi seluruh aspek kehidupan, termasuk dalam bidang ekonomi. Dalam kehidupan bermasyarakat, Bali memiliki potensi pembelajaran bagi kaum perempuan untuk memerankan diri dalam lingkup rumah tangga maupun publik. Perempuan Bali yang terikat pada adat harus menjalankan tiga peran (triple-roles) sekaligus yaitu: (1) peran rumah tangga, (2) peran ekonomi, dan (3) peran adat baik di keluarga, banjar maupun di desa adat sebagai tuntutan keseimbangan. Pemaknaan peran perempuan Bali terkait dengan empat tujuan

Tabel 4. Keterlibatan Peran Perempuan pada Tahap Panen.

Table 4. The Involvement of Women Role on Harvest Stage.

\begin{tabular}{|c|c|}
\hline Waktu/Time & Aktivitas/Activity \\
\hline $\begin{array}{l}\text { Pada saat air laut surut, biasanya pada pagi hari/Jika } \\
\text { pukul } 02.00 \text { WITA air sudah surut maka mereka harus } \\
\text { segera bangun dan memulai pekerjaan/ When sea } \\
\text { water recede usually in the morning lif } 02.00 \text { am WITA } \\
\text { water ran off and they should get up and began the } \\
\text { work }\end{array}$ & $\begin{array}{l}\text { Mengambil rumput laut di tambak. Pekerjaan ini } \\
\text { bisa dilakukan bersama-sama dengan laki-laki } \\
\text { maupun sendirian / Take seaweed in the ponds. } \\
\text { This work can be done together with men or } \\
\text { alone }\end{array}$ \\
\hline
\end{tabular}

Sumber: Data primer diolah (2013) / Source primary data processed (2013)

Tabel 5. Keterlibatan Peran Perempuan pada Tahap Pasca Panen. Table 5. The Involvement of Women Role in Post Harvest Stage.

\begin{tabular}{ll}
\hline \multicolumn{1}{c}{ Waktu / Time } & \multicolumn{1}{c}{ Aktivitas/Activity } \\
\hline Umumnya sejak selesai panen atau sejak pagi & Memilah rumput laut untuk dijual atau dijadikan \\
hari sampai sore atau pukul 14.00 WITA/Generally & bibit, rumput laut yang siap untuk dijual dibawa ke \\
since finished harvest or since morning till noon or & penjemuran / Sorting seaweed for sale or become \\
wita 2 p.m. WITA & seeds, seaweed ready for sale brought to dryed place
\end{tabular}

Sumber: Data primer diolah (2013) / Source primary data processed (2013) 
hidup yang hendak dicapai (catur purusa artha) dan harmonisasi Bali yang tertuang dalam konsep Tri Hita Karana. Konsep-konsep inilah yang tidak terlepas dari pemaknaan dan penyajian peran perempuan Bali.

Kebudayaan Bali merupakan salah satu kebudayaan yang menganut sistem patriarki dimana kedudukan laki-laki dinilai lebih tinggi dalam keluarga. Salah satu implementasi sistem patriarki yaitu dalam masalah waris dimana anak laki-laki memiliki hak waris sedangkan perempuan tidak. Hal ini menjadi salah satu faktor yang mendorong kaum perempuan Bali menjadi pekerja keras. Mereka tidak hanya bekerja sebagai ibu rumah tangga namun juga dapat melakukan pekerjaan yang umumnya dilakukan oleh kaum laki-laki seperti mengambil air dan bekerja di ruang publik.

Etos kerja perempuan pembudidaya rumput laut di Nusa Penida dikaitkan dengan konsep industrialisasi dan pembangunan ekonomi menunjukkan hal-hal yang positif. Hal ini karena didorong oleh kebudayaan yang dipengaruhi oleh konsep Tri Hita Karana. Sikap mental perempuan Bali yang rajin, ulet dan semangat dalam memberikan peran, baik dalam lingkup rumah tangga maupun publik menunjukkan bahwa sikap tersebut merupakan sebagai sikap kehendak yang dituntut agar dikembangkan di dalam masyarakat. Oleh karena itu, mereka tidak merasa berat dalam menjalankan setiap peran yang mereka jalankan karena ada perasaan malu jika mereka tidak dapat menjalankan peran-peran tersebut.

Sumber motivasi yang membuat perempuan pembudidaya rumput laut mau ikut terlibat dalam mata pencahariaan adalah keharusan saling bahu membahu antara laki-laki dengan perempuan. Sumber pendorong etos kerja ini adalah konsep Tri Hita Karana dimana bekerja dalam pandangan kaum perempuan pembudidaya rumput laut adalah 1) Tugas dan tanggung jawab yang sudah dibagi yang harus dipenuhi dalam relasi hubungan laki-laki dan perempuan; 2) Sebagai media untuk membantu suami dalam mencari nafkah; 3) Tugas dan tanggung jawab dalam relasi hubungan kerabat; 4) Kegiatan untuk mengisi waktu santai yang luang. Sistem nilai, keyakinan dan tuntutan akan kebutuhan menjadi faktor yang mempengaruhi etos kerja kaum perempuan pembudidaya rumput laut di Nusa Penida.

Sistem nilai dan keyakinan yang sudah tertanam pada diri perempuan Bali diwariskan secara turun temurun dalam keluarga dan diperkuat dengan keberadaan lembaga adat yaitu Desa Pekraman yang merupakan kumpulan dari desa adat banjar. Saat ini banyak terjadi pemekaran banjar yang disebabkan oleh karena faktor kependudukan, wilayah dan juga politik. Di Nusa Penida terdapat 16 desa administrasi dan lebih dari 100 desa pakraman. Satu desa pakraman terdiri paling sedikit 3 banjar dan paling banyak 7 banjar. Sistem kekerabatan yang ditunjukkan berdasarkan cakupan pura atau disebut Paibon juga menjadi menjadi dasar dalam melestarikan sistem nilai yang ada di dalam masyarakat. Sistem Paibon menjadi dasar kerjasama di dalam masyarakat. Aktivitas ekonomi, sosial dan kemasyarakatan berlangsung di dalam Paibon, salah satunya dalam kegiatan Ngaben (upacara pembakaran mayat). Setiap anggota masyarakat terikat dengan kewajiban pelaksanaan upacara-upacara adat di tempat mereka tinggal. Kewajiban adat ini bersifat kolektif dan mengikat setiap keluarga, sehingga tidak dimungkinkan seluruh anak atau keturunan dari satu keluarga untuk merantau, sementara orang tua atau aset yang dimiliki masih ada di desa tersebut. Keterikatan secara kolektif ini memberikan dampak yang positif dalam aktivitas ekonomi tertentu. Sebagai contoh, desa adat yang memiliki wilayah pesisir dan banyak terdapat usaha budidaya rumput laut membuat aturan adat (awik awik) yang bertujuan mencegah terjadinya tindak pencurian atau sengketa lahan.

Budidaya rumput laut saat ini menjadi mata pencaharian utama masyarakat. Sebelum ada budidaya rumput laut, para nelayan di Nusa Penida banyak yang melaut sampai ke Perairan Lombok hingga bermalam. Perkembangan industri pariwisata di Bali menciptakan pergeseranpergeseran budaya di Nusa Penida. Sejak tahun 1990-an, adat istiadat semakin ketat dan mulai ada pertemuan secara rutin sehingga nelayan tidak lagi dapat melaut hingga berhari-hari. Budidaya rumput laut dinilai dapat menjadi solusi dari ketatnya adat istiadat yang harus dipatuhi.

\section{Strategi Pemberdayaan dan Pengembangan Ekonomi Pembudidaya Rumput Laut}

Strategi pemberdayaan dan pengembangan ekonomi masyarakat membutuhkan pemahaman mendasar mengenai etos kerja sebagai dasar dalam menentukan arah kebijakan program dan implementasinya sehingga program dapat berhasil. Besarnya peranan perempuan dalam 
bidang ekonomi tidak secara otomatis membuat perempuan memiliki kesetaraan yang sama dengan kaum laki-laki. Kaum laki-laki masih dianggap memiliki kekuasaan yang besar baik dalam rumah tangga maupun dalam kehidupan bermasyarakat. Pada umumnya, walaupun kaum perempuan mempunyai peranan dalam pengambilan keputusan namun hanya sebagai orang kedua atau subordinat. Perempuan masih belum mendapatkan hak dan kedudukan yang sama dengan kaum laki-laki (Murniati dan Nunuk, 2004: 55-56). Untuk meningkatkan peran perempuan dalam ruang publik maka perempuan dan laki-laki dapat bekerja sama saling mengembangkan diri melalui relasi dalam bekerja. Saling ketergantungan antara perempuan dan laki-laki diwujudkan dalam bentuk partnerrelationship dengan pola hubungan horisontal bukan vertikal (hubungan kekuasaan) (Murniati dan Nunuk, 2004: 62-63).

Perempuan memiliki peluang yang besar dalam pembangunan. Strategi pemberdayaan dan pengembangan ekonomi pada kaum perempuan pembudidaya rumput laut di Nusa Penida antara lain dengan memberikan peluang-peluang kegiatan ekonomi yang lebih besar lagi dengan menyertakan peningkatan kapasitas pengetahuan dan keterampilan terkait dengan usaha budidaya rumput laut. Kaum perempuan tidak hanya diposisikan sebagai pemeran pembantu dalam pengembangan usaha budidaya rumput laut namun menjadi pemeran utama yang setara dengan kaum laki-laki.

Salah satu upaya untuk meningkatkan peran perempuan adalah dengan pemberdayaan perempuan. Salah satu upaya peningkatan peran perempuan berdasarkan konvensi organisasi dan undang-undang adalah perempuan dilibatkan dalam pengelolaan lingkungan hidup baik lingkungan alam, lingkungan sosial, dan budaya. Dengan meningkatkan peran perempuan dalam usaha budidaya rumput laut maka mereka akan lebih memiliki keterlibatan dalam pengambilan keputusan, perencana, penasihat teknis, pimpinan, dan sekaligus menjadi pengelola lingkungan hidup. Peningkatan peran perempuan tersebut pada akhirnya akan dikuatkan melalui hukum, konstitusi, administrasi, budaya, perilaku, sosial, dan ekonomi (Murniati dan Nunuk, 2004: 72-73).

Peran para perempuan pembudidaya rumput laut di Nusa Penida sangat besar. Hal ini didorong oleh etos kerja yang mereka miliki, sehingga mereka mendominasi peran dalam usaha budidaya rumput laut. Dengan etos kerja yang besar maka keberhasilan pemberdayaan perempuan akan lebih mudah terwujud.

\section{KESIMPULAN DAN IMPLIKASI KEBIJAKAN}

Peran perempuan di Nusa Penida terlihat dalam lingkup privat (rumah tangga) dan publik. Pada lingkup publik, kaum perempuan di Nusa Penida melakukan pekerjaan rumah tangga tanpa mengenal konsep ringan dan berat dalam suatu pekerjaan. Pada usaha budidaya rumput laut di Nusa Penida, peran perempuan sangat besar. Etos kerja perempuan pembudidaya rumput laut di Nusa Penida sangat besar. Etos kerja perempuan pembudidaya rumput laut di Nusa Penida yaitu rajin, semangat, pantang menyerah, kebersamaan, dan memiliki kemauan untuk maju. Etos kerja tersebut didorong oleh kebudayaan Bali yang mereka miliki sebagai sebuah penjabaran dari konsep Tri Hita Karana. Etos kerja perempuan pembudidaya rumput laut tersebut sangat mendukung pembangunan ekonomi.

Strategi pemberdayaan dan pengembangan ekonomi yang dapat dilakukan pada pembudidaya rumput laut di Nusa Penida adalah dengan memberikan peluang-peluang kegiatan ekonomi yang lebih besar lagi dengan menyertakan peningkatan kapasitas pengetahuan dan keterampilan terkait dengan usaha budidaya rumput laut. Kaum perempuan tidak hanya diposisikan sebagai pemeran pembantu dalam pengembangan usaha budidaya rumput laut namun menjadi pemeran utama yang mampu setara dengan kaum laki-laki.

\section{DAFTAR PUSTAKA}

Antara, 2012. "Menteri: Percepatan Industrialisasi Perikanan Ditentukan Delapan Faktor", 23 November 2012.https:// id.berita.yahoo.com/menteri-percepatan-industrialisasi-perikanan-ditentukan-delapan-faktor-040407991.html (diakse tanggal 18 Februari 2014).

Chrysantini, P. 2010. Di Balik Panggung Reforma Agraria: Perjuangan Tersembunyi Perempuan Tani. Antropologi Indonesia Vol. 31 (3): 185-199.

Murniati, A. \& Nunuk P. 2004. Getar Gender: Perempuan Indonesia dalam Perspektif Agama, Budaya dan Keluarga. Magelang: Indonesiatera. 
Nasution, Z., N. Kurniasari, F. Nurpriyatna, C. Yuliaty \& Nurlaili. 2013. Laporan Akhir Kajian Sosio Antropologi Masyarakat Perikanan Pada Kawasan MP3EI. Jakarta: Balai Besar Penelitian Sosial Ekonomi Kelautan dan Perikanan, Badan Penelitian dan Pengembangan Kelautan dan Perikanan, Kementerian Kelautan dan Perikanan.

Nurlaili \& S. Koeshendrajana. 2010. Peran Perempuan Bajo dalam Rumah Tangga Perikanan Tangkap di Desa Wuring, Kecamatan Alok Barat, Kabupaten Sikka, Propinsi Nusa Tenggara Timur. Jurnal Kebijakan dan Riset Sosial Ekonomi Kelautan dan Perikanan, Vol 5(2): 199-210.

Siswanto, D. 2011. Urgensi Falsafah Penyuluhan Pembangunan dan Etos Kerja dalam Pemberdayaan Masyarakat. Makalah unpublished.
Tirtayani, L.A. 2010. Wanita Bali dalam Pemaknaan Peran (Studi Fenomenologis terhadap Triple-Roles Wanita Bali, di Desa Adat Kuta). Makalah unpublished.

Welly, M., W. Sanjaya, D. Trimudya \& W.G. Yanto. 2012. Profil Perikanan Nusa Penida, Kabupaten Klungkung, Propinsi Bali. Bali: Pemerintah Kabupaten Klungkung dan Coral Triangle Center.

Witomo, C.M. \& Hikmah. 2012. Peran Perempuan Pesisir dalam Rumah Tangga (Studi Kasus Pembudidaya Rumput Laut di Desa Batu Nunggul, Nusa Penida). Prosiding Seminar Nasional Perikanan Indonesia, 13-14 November 2012. Jakarta: Sekolah Tinggi Perikanan. 